DOI: http://dx.doi.org/10.1590/1678-457X.6373

\title{
Ability of a Lactobacillus rhamnosus strain cultured in milk whey based medium to bind aflatoxin $B$
}

\author{
Fernanda $\mathrm{BOVO}^{1}$, Larissa Tuanny FRANCO ${ }^{1}$, Roice Eliana ROSIM $^{1}$, Carlos Augusto Fernandes de OLIVEIRA ${ }^{1 *}$
}

\begin{abstract}
This study aimed to compare Lactobacillus rhamnosus growth in MRS (de Man, Rogosa and Sharpe) broth and a culture medium containing milk whey (MMW) and to evaluate aflatoxin $\mathrm{B}_{1}\left(\mathrm{AFB}_{1}\right)$ adsorption capacity by bacterial cells produced in both culture media. L. rhamnosus cells were cultivated in MRS broth and MMW $\left(37^{\circ} \mathrm{C}, 24\right.$ hours), and bacterial cell concentration was determined spectrophotometrically at $600 \mathrm{~nm}$. $\mathrm{AFB}_{1}(1 \mu \mathrm{g} / \mathrm{ml})$ adsorption assays were conducted using $1 \mathrm{x} 10^{10} \mathrm{non}$-viable L. rhamnosus cells $\left(121^{\circ} \mathrm{C}, 15\right.$ minutes) at $\mathrm{pHs} 3.0$ and 6.0 and contact time of 60 minutes. $\mathrm{AFB}_{1}$ quantification was performed by High Performance Liquid Chromatography. Bacterial cell concentration in MMW was higher $(9.84 \log \mathrm{CFU} / \mathrm{ml})$ than that in MRS broth $(9.63 \log \mathrm{CFU} / \mathrm{ml})$. There were no significant differences between AFB binding results at the same $\mathrm{pH}$ value $(3.0$ or 6.0) for the cells cultivated in MRS broth (46.0\% and 35.8\%, respectively) and in MMW (43.7\% and 25.8\%, respectively), showing that MMW can adequately replace the MRS broth. Therefore, it can be concluded that the use of L. rhamnosus cells cultivated in MMW offers advantages such as reduction in large scale production costs, improvement of environmental sustainability, and being a practicable alternative for decontamination of food products susceptible to aflatoxin contamination.
\end{abstract}

Keywords: aflatoxin $\mathrm{B}_{1}$; decontamination; lactic acid bacteria; milk whey; MRS broth.

\section{Introduction}

Lactic acid bacteria (LAB) are genetically diverse bacteria that produce lactic acid as the main product of their metabolism. They are Gram-positive, catalase and oxidase negative bacteria; they do not form spores and move spontaneously; furthermore, they grow anaerobically but are aero-tolerant (Walstra et al., 2006). Lactobacillus, Lactococcus, Leuconostoc, Pediococcus, and Streptococcus are examples of LAB genus known as starter cultures in the food and beverage, fermented vegetables, cereals, milk, and meat industries. Considering their implication in food processing and their presence in the healthy microbiota of the human gastrointestinal tract, LAB are "generally recognized as safe" (GRAS) (Thipathi et al., 2012).

In addition to the use of $\mathrm{LAB}$ as fermentative agents in food products, a new approach that has aroused great interest among researchers is their use as aflatoxin decontaminating agents. Aflatoxins are mycotoxins produced by species of Aspergillus flavus and Aspergillus parasiticus, widely used in food and feed, which have remarkable toxic properties including carcinogenic, mutagenic, teratogenic, immunosuppressive, and hepatotoxic effects in humans and animals (Alberts et al., 2006). Eighteen different types of aflatoxins have been identified so far, and aflatoxin $\mathrm{B}_{1}\left(\mathrm{AFB}_{1}\right)$ is the most prevalent and toxic metabolite produced by the fungi (Bhat et al., 2010). Several studies have demonstrated the efficiency of different species and strains of LAB in adsorbing aflatoxins from contaminated media (El-Nezami et al., 1998; Pierides et al., 2000; Oatley et al., 2000; Haskard et al., 2001; Peltonen et al., 2001; Azab et al., 2005; Fazeli et al., 2009; Bovo et al., 2013).

LAB necessarily ferment sugars and tend to be nutritionally demanding, requiring specific amino acids and $\mathrm{B}$ vitamins as growth factors (Walstra et al., 2006). Lactose is the major carbon source for $\mathrm{LAB}$, and it is metabolized mainly to lactic acid. Bibal et al. (1988) observed that when the $\mathrm{pH}$ decrease resulting from lactic acid accumulation in the medium is not controlled, the cessation of LAB growth occurs concomitantly with the acidification of the culture from $\mathrm{pH} 6.3$ to $\mathrm{pH} 4.5$, which can sometimes cause the incomplete utilization of lactose. Van de Guchte et al. (2002) explained that acids can passively diffuse through the bacterial cell membrane and, after entry into the cytoplasm, rapidly dissociate into protons and charged derivatives to which the cell membrane is impermeable causing an internal acidification that reduces the activity of acidsensitive enzymes and damages proteins and DNA. Thus, it is important to monitor these conditions during the fermentation in order to favor bacterial growth.

LAB are often cultivated in specific and standardized media, for example, MRS (de Man, Rogosa \& Sharpe) broth. However, commercially available culture media with high specificity are generally expensive and are only used in laboratories for small scale production. In the case of large scale production, it is necessary to search for specific low cost culture medium. Currently, there has been an increase in demand for culture media produced with food industry byproducts, such as milk whey.

Resulting from the production of dairy products such as cheese, milk whey is rich in nutrients, for example, lactose, soluble proteins, lipids and minerals, retaining about $55 \%$ of total milk nutrients. Although several possibilities of milk whey utilization have been explored, in a major portion of the world, milk whey production is discarded as effluent. Its 
disposal as waste poses serious pollution problems for the surrounding environment (Panesar et al., 2007). According to the International Dairy Federation (International Dairy Federation, 2009), milk production raised 24\% between 1998 and 2008 , with the same $24 \%$ increase in cheese production, mostly in Latin America, demonstrating the wide availability of this byproduct for LAB production. Therefore, the aim of this study was to compare the growth of a LAB strain in standard culture medium (MRS broth) and in culture medium containing milk whey and to evaluate the adsorption capacity of $\mathrm{AFB}_{1}$ by bacterial cells produced by both culture media.

\section{Materials and methods}

\subsection{L. rhamnosus and culture conditions in MRS broth}

The LAB strain used in this study was L. rhamnosus HOWARU $^{\circledR}$ LYO 40 DCU, kindly donated by Danisco Brazil Ltda. The lyophilized strain was reactivated in MRS broth (Acumedia ${ }^{\circledR}$, Lansing, MI, USA), composition shown in Table 1 , at $37^{\circ} \mathrm{C}$ for 24 hours and grown under these conditions until achieving high cell concentration $\left(>10^{9} \mathrm{cells} / \mathrm{ml}\right)$. Estimation of bacterial cell concentration was determined by the turbidimetric method (Begot et al., 1996). A bacterial cell concentration curve was constructed using the absorbance measured at $600 \mathrm{~nm}$ (Spectrumlab 22PC - Shanghai Lengguang Technology Co. Ltd, Shanghai, China) and the logarithmic value of bacterial cell concentration obtained by dilution and pour plate counting (Wehr \& Frank, 2004) after incubation in MRS agar (Acumedia ${ }^{\circledR}$, Lansing, MI, USA) at $37^{\circ} \mathrm{C}$ for 48 hours under anaerobic conditions. From these data, an equation to calculate bacterial cell concentration in the medium was generated, which adapted perfectly to the data since its coefficient of determination $\left(\mathrm{R}^{2}\right)$ was 0.999 .

\subsection{Culture conditions in medium containing milk whey}

L. rhamnosus was cultivated in a medium containing milk whey (MMW) in its composition; Table 1 shows this medium composition. To prevent protein precipitation during

Table 1. Composition of MRS broth and medium containing milk whey.

\begin{tabular}{|c|c|c|}
\hline Components & MRS broth & $\begin{array}{c}\text { Medium } \\
\text { containing } \\
\text { milk whey }\end{array}$ \\
\hline Peptone $(\mathrm{g} / \mathrm{L})$ & 10 & 20 \\
\hline Yeast Extract (g/L) & 4 & 10 \\
\hline Meat Extract (g/L) & 8 & - \\
\hline Glucose $(\mathrm{g} / \mathrm{L})$ & 20 & - \\
\hline Tween $80(\mathrm{~g} / \mathrm{L})$ & 1 & - \\
\hline Photassium Phosphate Dibasic (g/L) & 2 & - \\
\hline Sodium Acetate. $3 \mathrm{H}_{2} \mathrm{O}(\mathrm{g} / \mathrm{L})$ & 5 & - \\
\hline Tri-ammonium Citrate (g/L) & 2 & - \\
\hline Magnesium Sulfate. $7 \mathrm{H}_{2} 0(\mathrm{~g} / \mathrm{L})$ & 0.2 & 0.2 \\
\hline Manganese Sulfate. $\mathrm{H}_{2} \mathrm{O}(\mathrm{g} / \mathrm{L})$ & 0.04 & 0.04 \\
\hline Milk Whey Powder (g/L) & - & 70 \\
\hline Commercial Protease $^{B}(\mu \mathrm{L} / \mathrm{L})$ & - & 500 \\
\hline
\end{tabular}

sterilization $\left(121^{\circ} \mathrm{C}, 15\right.$ minutes), proteins were hydrolyzed with a commercial protease, and to prevent Maillard reaction, peptone and yeast crude extract were added subsequently under aseptic conditions.

Another bacterial cell concentration curve was constructed correlating the bacterial growth in MMW and the absorbance measured spectrophotometrically at $600 \mathrm{~nm}\left(\mathrm{R}^{2}=0.999\right.$; Begot et al., 1996). The assays were conducted in $1 \mathrm{~L}$ Erlenmeyer flasks at $37^{\circ} \mathrm{C}$ for 24 hours. $25 \mathrm{ml}$ samples were withdrawn at the beginning and the end of the experiment to quantify the biomass produced to determine the lactose concentration and to monitor the $\mathrm{pH}$ levels (PHS-3B - PHTEK, Curitiba/PR/Brazil) due to the production of lactic acid.

\subsection{Lactose determination}

Lactose was determined using the DNS Method (dinitrosalicylic acid) proposed by Miller (1959). Lactose PA (Synth, Diadema/SP/Brazil) was used as the standard, and the DNS reagent was prepared by mixing $50 \mathrm{ml}$ of sodium hydroxide 2 N, 2.5 g of 3,5-dinitrosalicylic acid (Vetec Química Fina Ltda., Rio de Janeiro/RJ/Brazil) and $125 \mathrm{ml}$ of distilled water. After complete dissolution, $75 \mathrm{~g}$ of sodium potassium tartrate were added (Qhemis, Indaiatuba/SP/Brazil), and the volume was completed to $250 \mathrm{ml}$ with distilled water. DNS reagent was kept protected from light.

The analysis consisted of sample dilution to the range of lactose concentration in the curve constructed ( 0 to $2 \mathrm{~g} / \mathrm{L}$ ), which correlates lactose concentration with absorbance at $540 \mathrm{~nm}\left(\mathrm{R}^{2}=0.995\right)$.

One $\mathrm{ml}$ of the diluted sample and $2 \mathrm{ml}$ of the DNS reagent were added in a glass tube and vortexed before heating in water bath at $100{ }^{\circ} \mathrm{C}$ for 5 minutes. The sample was cooled to room temperature, and $22 \mathrm{ml}$ of distilled water were added and vortexed again, and, finally, the spectrophotometric absorbance was read at $540 \mathrm{~nm}$.

\subsection{AFB ${ }_{1}$ adsorption assays}

$\mathrm{AFB}_{1}$ standard (Supelco ${ }^{\mathrm{Tm}}$, Bellefonte, PA, USA) was dissolved in toluene and acetonitrile (9:1) and calibrated in spectrophotometer, according to Scott (1990), in order to obtain a $10.0 \mu \mathrm{g} \mathrm{AFB}_{1} / \mathrm{ml}$ stock solution. A $1.0 \mu \mathrm{g} \mathrm{AFB}_{1} / \mathrm{ml}$ working solution was prepared in a citrate-phosphate buffer solution $(\mathrm{pH}$ 3.0 and $\mathrm{pH}$ 6.0) using a combination of $0.1 \mathrm{M}$ citric acid (Synth, Diadema, SP, Brazil) and 0.2 M di-basic sodium phosphate (Süd Chemie, Jacareí, SP, Brazil) solutions. The solvent was completely evaporated by direct air injection in a heating bath (TE-019 -Tecnal, Piracicaba, SP, Brazil) at $40{ }^{\circ} \mathrm{C}$.

The L. rhamnosus cells produced in MRS broth or MMW were inactivated by sterilization $\left(121^{\circ} \mathrm{C}, 15\right.$ minutes $)$ because even non-viable cells are able to adsorb the $\mathrm{AFB}_{1}$ (Bovo et al., 2013). The AFB binding assays were conducted using the method described by El-Nezami et al. (1998) with some adaptations. Aliquots of the culture broth containing $1 \times 10^{10}$ cells were transferred to test tubes and centrifuged (CT-14 000 - Cientec, Piracicaba, SP, Brazil) at $1800 \times \mathrm{g}$ for 
5 minutes. The bacterial pellets were washed with sterile ultra-pure water, re-suspended in $1.5 \mathrm{ml}$ of buffer solutions $\left(\mathrm{pH} 3.0\right.$ and 6.0) containing $\mathrm{AFB}_{1}$, and incubated under agitation of $180 \mathrm{rpm}$ (TE-140 - Tecnal, Piracicaba, SP, Brazil) for 60 minutes at room temperature. After incubation, the solution was centrifuged at $1800 \times \mathrm{g}$ for 5 minutes, and the supernatant was removed and released $\mathrm{AFB}_{1}$ was quantified by high performance liquid chromatography (HPLC). The analyses were performed in triplicate and, for each sample, negative (L. rhamnosus cells suspended in buffer solution) and positive ( $A F B_{1}$ in buffer solution) controls were incubated and analyzed.

\subsection{AFB ${ }_{1}$ quantification by HPLC}

$\mathrm{AFB}_{1}$ quantification in the buffer solutions was achieved by injection into a HPLC system equipped with a fluorescence detector RF-10A XL, an autosampler SIL-10AF (Shimadzu ${ }^{\circledR}$, Tokyo, Japan), and an ODS column $5 \mu \mathrm{m} 4.6 \times 150 \mathrm{~mm}$ (Phenomenex ${ }^{\circledR}$, Torrance, USA). A flow rate of $1.0 \mathrm{ml} / \mathrm{min}$ was used with a mobile phase containing water, acetonitrile, and methanol (60:20:20). Excitation and emission detection were set at the wavelength of $360 \mathrm{~nm}$ and $440 \mathrm{~nm}$, respectively. The limit of detection (LOD) for $\mathrm{AFB}_{1}$ was $0.01 \mathrm{ng} / \mathrm{ml}$, and its retention time was 10.5 minutes with a retention window of $\pm 10 \%$. Equation 1 was used to quantify $A F B$, where $\mathrm{A}$ is the percentage of $A F B_{1}$ bound by the sample, and $B, C$, and $D$ are the areas of chromatographic peaks of positive control, sample, and negative control, respectively.

$\mathrm{A}=[(\mathrm{B}-\mathrm{C}-\mathrm{D}) / \mathrm{B}] * 100$

\subsection{Statistical analysis}

Results were subjected to analysis of variance, in accordance with the procedures established in the General Linear Model of SAS ${ }^{\circledR}$ (SAS Institute Inc., 1992), to check for significant differences between means of variables in the different treatments. The Fisher LSD test (Least Significant Difference) was used to test significant differences between means, adopting $\alpha=0.05$ as rejection level.

\section{Results and discussion}

Greater quantities of $L$. rhamnosus cells were achieved at lower costs using MMW (9.84 log CFU/ml) when compared with the MRS broth (9.63 $\log \mathrm{CFU} / \mathrm{ml}$ ), a medium specifically developed for growing of Lactobacillus bacteria. Thus, MMW can perfectly replace the MRS broth for L. rhamnosus production, without affecting cell production.

The lactose concentration in MMW decreased approximately by half, from $63.9 \mathrm{~g} / \mathrm{L}$ to $35.3 \mathrm{~g} / \mathrm{L}$, while the $\mathrm{pH}$ decreased from 6.1 to 3.5. Lactose fermentation by L. rhamnosus, a homofermentative bacterium, produces lactic acid, which acidifies the medium causing a decrease in the $\mathrm{pH}$. Ostile et al. (2003) also observed that the $\mathrm{pH}$ of a medium produced with UHT milk and supplemented with $0.75 \%$ of fructose had declined from 6.7 to 4.1 after 24 hours when L. rhamnosus (strain GG) was cultured. The authors also observed that bacterial cell concentration in the medium was $9.2 \mathrm{log} \mathrm{CFU} / \mathrm{ml}$ after 24 hours.
Narvhus et al. (1998) explained that lactose is the primary substrate for acid production in milk; however, its fermentation is not limited by the amount of lactose available, but by the production of lactic acid and the concomitant lowering of $\mathrm{pH}$, which increasingly inhibits the starter organisms long before the lactose is exhausted. According to Panesar et al. (2007), a complete and rapid fermentation occurs at the optimal $\mathrm{pH}$ range of 5.5-6.0, and in some cases, in the range of 6.0-6.5, depending upon the culture used, and it is strongly inhibited at lower $\mathrm{pH}$ values, stopping at $\mathrm{pH}$ below 4.5. However, LAB acid tolerance gives them a competitive advantage over many other bacteria. These authors added that $\mathrm{pH}$ affects some aspects of microbial cells, i.e., the functioning of their enzymes, transport of nutrients into the cell, and RNA and protein synthesis. In the present study, although the $\mathrm{pH}$ was below the ideal $\mathrm{pH}$ range for optimal cell growth, the growth rates of $L$. rhamnosus cultivated in MMW was higher than that in MRS broth.

Arauz et al. (2012) explained that LAB production is a meticulous process due to their nutrient demand. In laboratoryscale studies, LAB are usually grown in standard medium such as MRS broth, but the use of this medium in large scale becomes rather expensive. Therefore, complex and expensive culture media should be replaced with simpler and cheaper culture media to improve the LAB commercial production since, according to Rodrigues et al. (2006), the culture medium may represent $30 \%$ of the cost of a microbial fermentation. Burns et al. (2008) observed that the major benefits of using milk whey are its nutritional value and reasonable cost. Furthermore, possible environmental problems are avoided since the disposal of this by-product with a high load of organic matter can harm the environment. According to Mizubuti (1994), if 50,000 liters of milk whey were released as effluent, they would be equivalent to the sewage of a town of 25,000 inhabitants.

The results obtained for the adsorption of $\mathrm{AFB}_{1}$ by L. rhamnosus cells produced in MRS broth and in MMW are shown in Table 2. It can be seen that, at the same $\mathrm{pH}$ value (3.0 or 6.0), there were no significant differences between the two culture media analyzed. The MMW was the only one that showed significant differences between both $\mathrm{pHs}$, and the $\mathrm{AFB}_{1}$ was better adsorbed by the bacterial cells at $\mathrm{pH} 3.0$ These results show that changing the culture medium did not affect the ability of L. rhamnosus to adsorb aflatoxins at a given $\mathrm{pH}$ value, which means that probably there were no changes in the bacterial cell structure.

According to Bata \& Lásztity (1999) and Lahtinen et al. (2004), adsorption of $\mathrm{AFB}_{1}$ by bacteria possibly occurs through a physical union between the toxin and the microorganism, an adhesion to the bacterial cell wall components, particularly to the polysaccharides and peptidoglycans instead of covalent bonding or degradation by the metabolism of bacteria. Therefore, it is assumed that the greater the number of bacterial cells in the medium, the greater the amount of aflatoxin adsorbed by the bacteria. Ringot et al. (2007) explained that the complexity of microbial structure implies in the existence of several ways for the toxin to be captured by the cells. The sorption on the cell surface is a fast physicochemical interaction between the toxin and the functional groups of the cell surface, and it is based on 
Table 2. $\mathrm{AFB}_{1}$ adsorption capacity of cells of L. rhamnosus cultured in MRS broth and in a medium containing milk whey.

\begin{tabular}{lccc}
\hline \multirow{2}{*}{ Culture medium for L. rhamnosus, } & \multicolumn{2}{c}{$\mathrm{AFB}_{1}$ Adsorption $(\%)^{\mathrm{C}, \mathrm{D}}$} & $\mathrm{pH} 6.0$ \\
\cline { 2 - 4 } & $\mathrm{pH} \mathrm{3.0}$ & $35.8 \pm 7.7$ & 0.2072 \\
\hline MRS Broth & $46.0 \pm 8.8$ & $25.8 \pm 0.4$ & 0.0177 \\
Medium containing milk whey & $43.7 \pm 8.0$ & 0.0879 & \\
P-value & 0.7676 & \\
\hline
\end{tabular}

${ }^{\mathrm{A}}$ L. rhamnosus strain HOWARU ${ }^{\otimes} \mathrm{LYO} 40 \mathrm{DCU} ;{ }^{\mathrm{B}}$ Non-viable cells produced by sterilization at $121{ }^{\circ} \mathrm{C}$ for 15 minutes; ${ }^{\mathrm{C}} \mathrm{AFB}$ removed from a citrate-phosphate buffer containing $1.0 \mu \mathrm{g}$ $\mathrm{AFB}_{1} / \mathrm{ml}$; ${ }^{D}$ Values expressed as mean \pm standard deviation of samples analyzed in triplicate.

physical adsorption, ion exchange, and complexation, regardless of the bacterial metabolism. The cell wall of microorganisms is mainly composed by polysaccharides, proteins, and lipids, which contain abundant functional groups such as carboxyl, hydroxyl, phosphate, and amine and hydrophobic adsorption sites, such as aliphatic carbon chains and aromatic rings.

Haskard et al. (2001) and El-Nezami et al. (1998) analyzed viable cells of L. rhamnosus (strains GG and LC-705) and obtained about $80 \%$ of $\mathrm{AFB}_{1}$ binding from a contaminated medium. Rahaie et al. (2012) observed that heat treated cells of L. rhamnosus GG could adsorb $85 \%$ of $\mathrm{AFB}_{1}(10 \mathrm{ng} / \mathrm{ml})$ from the medium. Peltonen et al. (2001) also studied viable cells of L. rhamnosus (strains E-97800, LC 1/3 and CSCC 2420) and found $\mathrm{AFB}_{1}$ binding percentages of $22.7 \%, 54.6 \%$ and $33.1 \%$, respectively. It can observed that within a genus or even within a determined species, not all strains are equivalent in terms of toxin removal, on the contrary, aflatoxin binding capacity is a characteristic of only specific strains, and its effectiveness varies markedly (El-Nezami et al., 2004).

The use of heat treated bacterial cells in the $\mathrm{AFB}_{1}$ adsorption assays instead of viable cells was chosen because, as mentioned and proved before, even non-viable bacterial cells can remove the aflatoxin from the medium, and this would allow the drying of bacterial cells and the development of a new product that could be used in two different ways. In the first way, applicable to liquid products, dried bacterial cells would be added to the product for a certain period of time, and then $\mathrm{AFB}_{1}$ adsorption would occur without causing fermentation or damage to the product. Bacterial cells would be removed at the end of this process, resulting in a totally or partially decontaminated product. In the second way, the application would be in solid products, in which dried bacterial cells would be used as food additives, and the $\mathrm{AFB}_{1}$ adsorption process would occur in the gastrointestinal tract, preventing toxin absorption by the organism.

Comparing the results obtained in the present study with those of previous reports is difficult because there are no studies describing the production of bacterial cells in MMW followed by $\mathrm{AFB}_{1}$ adsorption assays in buffer solution. The studies published so far have addressed two different procedures: LAB cells produced in MRS broth and analyzed for aflatoxin adsorption capacity in buffer solution, as shown by Oatley et al. (2000), Lahtinen et al. (2004), Shahin (2007) or Fazeli et al. (2009); or, aflatoxin adsorption assays were performed directly in the dairy product, for example, in milk samples, but in this case, the adsorption of aflatoxin $\mathrm{M}_{1}$, an 4-hydroxylated metabolite derivative from $\mathrm{AFB}_{1}$ biotransformation in the liver of animals that had been fed with contaminated diet, was performed, as shown in studies of Pierides et al. (2000), Sarimehmetoglu \& Küplülü (2004), Elgerbi et al. (2006) and Bovo et al. (2013).

\section{Conclusions}

The results of this trial showed that the production of L. rhamnosus cells in MMW did not affect their adsorption capacity for $\mathrm{AFB}_{1}$. The production of greater quantities of $L$. rhamnosus cells at lower cost was accomplished using MMW, which had a higher cell concentration compared with that of MRS broth, a medium specifically developed for growing of Lactobacillus bacteria. Therefore, the use of a L. rhamnosus strain which is able to grow in the milk-whey based medium tested and adsorb aflatoxins has a potential application for aflatoxin decontamination in food products.

\section{Acknowledgements}

The authors are grateful to Fundação de Amparo à Pesquisa do Estado de São Paulo for the grant and financial support (Grant number 2011/03410-0).

\section{References}

Alberts, J. F., Engelbrechta, Y., Steynb, P. S., Holzapfelc, W. H., \& Van Zyla, W. H. (2006). Biological degradation of aflatoxin B1 by Rhodococcus erythropolis cultures. International Journal of Food Microbiology, 109(1-2), 121-126. PMid:16504326. http://dx.doi. org/10.1016/j.ijfoodmicro.2006.01.019

Arauz, L. J., Jozala, A. F., Baruque-Ramos, J., Mazzola, P. G., Pessoa Jr., A., \& Penna, T. C. V. (2012). Culture medium of diluted skimmed milk for the production of nisin in batch cultivations. Annals of Microbiology, 62(1), 419-426. http://dx.doi.org/10.1007/s13213011-0278-6

Azab, R. M., Tawakkol, W. M., Hamad, A. M., Abou-Elmagd, M. K., El-Agrab, H. M., \& Refai, M. K. (2005). Detection and estimation of aflatoxin B1 in feeds and its biodegradation by bacteria and fungi. Egyptian Journal of Natural Toxins, 2, 39-56.

Bata, A., \& Lásztity, R. (1999). Detoxification of mycotoxincontaminated food and feed by microorganisms. Trends Food Science and Technology, 10(6-7), 223-228. http://dx.doi.org/10.1016/ S0924-2244(99)00050-3

Begot, C., Desnier, I., Daudin, J. D., Labadie, J. C., \& Lebert, A. (1996). Recommendations for calculating growth parameters by optical density measurements. Journal of Microbiological Methods, 25(3), 225-232. http://dx.doi.org/10.1016/0167-7012(95)00090-9

Bhat, R., Rai, R. V., \& Karim, A. A. (2010). Mycotoxins in food and feed: present status and future concerns. Comprehensive Reviews in Food Science and Food Safety, 9(1), 57-81. http://dx.doi.org/10.1111/ j.1541-4337.2009.00094.x 
Bibal, B., Goma, G., Vayssier, Y., \& Pareilleux, A. (1988). Influence of $\mathrm{pH}$, lactose and lactic acid on the growth of Streptococcus cremoris: a kinetic study. Applied Microbiology and Biotechnology, 28(4-5), 340-344. http://dx.doi.org/10.1007/BF00268192

Bovo, F., Corassin, C. H., Rosim, R. E., \& Oliveira, C. A. F. (2013). Efficiency of lactic acid bacteria strains for decontamination of aflatoxin M1 in phosphate buffer saline solution and in skimmed milk. Food and Bioprocess Technology, 6(8), 2230-2234. http://dx.doi. org/10.1007/s11947-011-0770-9

Brinques, G. B. (2009). Otimização da produção de probióticos em biorreatores e suas aplicações em sistemas alimentícios sob a forma imobilizada (Tese de doutorado). Escola de Engenharia, Universidade Federal do Rio Grande do Sul, Porto Alegre. PMid:19936814.

Burns, P., Vinderola, G., Molinari, F., \& Reinheimer, J. (2008). Suitability of whey and buttermilk for the growth and frozen storage of probiotic lactobacilli. International Journal of Dairy Technology, 61(2), 156-164. http://dx.doi.org/10.1111/j.1471-0307.2008.00393.x

Elgerbi, A. M., Aidoo, K. E., Candlish, A. A. G., \& Williams, A. G. (2006). Effects of lactic acid bacteria and bifidobacteria on levels of aflatoxin M1 in milk and phosphate buffer. Milchwissenschaft, 61(2), 197-199.

El-Nezami, H., Kankaanpaa, P., Salminen, S., \& Ahokas, J. (1998). Ability of dairy strains of lactic acid bacteria to bind a common food carcinogen, aflatoxin B1. Food and Chemical Toxicology, 36(4), 321-326. http://dx.doi.org/10.1016/S0278-6915(97)00160-9

El-Nezami, H., Salminen, S., Salminen, E., Haskard, C., \& Mykkanen, H. (2004). Lactic acid bacteria as a tool for enhancing food safety by removal of dietary toxins. In S. Salminen, A. Von Wright \& A. Ouwehand, A. (Eds.), Lactic acid bacteria: microbiological and functional aspects (3rd ed., Cap. 12, pp. 397-406). New York: Marcel Dekker.

Fazeli, M. R., Hajimohammadali, M., Moshkani, A., Samadi, N., Jamalifar, H., Khoshayand, M. R., Vaghari, E., \& Pouragahi, S. (2009). Aflatoxin B1 binding capacity of autochthonous strains of lactic acid bacteria. Journal of Food Protection, 72(1), 189-192. PMid:19205485.

Haskard, C. A., El-Nezami, H. S., Kankaanpää, P. E., Salminen, S., \& Ahokas, J. T. (2001). Surface binding of aflatoxin B1 by lactic acid bacteria. Applied and Environmental Microbiology, 67(7), 3086-3091. PMid:11425726 PMCid:PMC92985. http://dx.doi.org/10.1128/ AEM.67.7.3086-3091.2001

International Dairy Federation. (2009). The World Dairy Situation 2009. In International Dairy Federation. Bulletin of the International Dairy Federation (Vol. 438). Brussels. Retrieved from http://www. lactodata.com/lactodata/docs/lib/fil_idf_bulletin_438_2009_the_ world_2009.pdf

Lahtinen, S. J., Haskard, C. A., Ouwehand, A. C., Salminen, S. J., \& Ahokas, J. T. (2004). Binding of aflatoxin B1 to cell wall components of Lactobacillus rhamnosus strain GG. Food Additives and Contaminants, 21(2), 158-164. PMid:14754638. http://dx.doi. org/10.1080/02652030310001639521

Miller, G. L. (1959). Use of dinitrosalicylic acid reagent for determination of reducing sugar. Analytical Chemistry, 31(3), 426428. http://dx.doi.org/10.1021/ac60147a030

Mizubuti, I. Y. (1994). Soro de leite: composição, processamento e utilização na alimentação. Semina: Ciências Agrárias, 15(1), 80-94.

Narvhus, J. A., Osteraas, K., Mutukumira, T., \& Abrahamsen, R. K. (1998). Production of fermented milk using a malty compoundproducing strain of Lactococcus lactis subsp. lactis biovar. diacetylactis, isolated from Zimbabwean naturally fermented milk.
International Journal of Food Microbiology, 41(1), 73-80. http:// dx.doi.org/10.1016/S0168-1605(98)00036-1

Oatley, J. T., Rarick, M. D., Ji, G. E., \& Linz, J. E. (2000). Binding of aflatoxin B1 to bifidobacteria in vitro. Journal of Food Protection, 63(8), 1133-1136. PMid:10945592.

Ostile, H. M., Helland, M. H., \& Narvhus, J. A. (2003). Growth and metabolism of selected strains of probiotic bacteria in milk. International Journal of Food Microbiology, 87(1-2), 17-27. http:// dx.doi.org/10.1016/S0168-1605(03)00044-8

Panesar, P. S., Kennedym, J. F., Gandhi, D. N., \& Bunko, K. (2007). Bioutilisation of whey for lactic acid production. Food Chemistry, 105(1), 1-14. http://dx.doi.org/10.1016/j.foodchem.2007.03.035

Peltonen, K., El-Nezami, H., Haskard, C., Ahokas, J., \& Salminen, S. (2001). Aflatoxin B1 binding by dairy strains of lactic acid bacteria and bifidobacteria. Journal of Dairy Science, 84(10), 2152-2156. http://dx.doi.org/10.3168/jds.S0022-0302(01)74660-7

Pierides, M., El-Nezami, H., Peltonen, K., Salminen, S., \& Ahokas, J. (2000). Ability of dairy strains of lactic acid bacteria to bind aflatoxin M1 in a food model. Journal of Food Protection, 63(5), 645-650. PMid:10826723.

Rahaie, S., Emam-Djomeh, Z., Razavi, S. H., \& Mazaheri, M. (2012). Evaluation of aflatoxin decontaminating by two strains of Saccharomyces cerevisiae and Lactobacillus rhamnosus strain GG in pistachio nuts. International Journal of Food Science and Technology, 47(8), 1647-1653. http://dx.doi.org/10.1111/j.13652621.2012.03015.x

Ringot, D., Lerzy, B., Chaplain, K., Bonhoure, J-P., Auclair, E., \& Larondelle, Y. (2007). In vitro biosorption of ochratoxin A on the yeast industry by-products: Comparison of isotherm models. Bioresource Technology, 98(9), 1812-1821. PMid:16919938. http:// dx.doi.org/10.1016/j.biortech.2006.06.015

Rodrigues, L. R., Teixeira, J. A., \& Oliveira, R. (2006). Low-cost fermentative medium for biosurfactant production by probiotic bacteria. Biochemical Engineering Journal, 32(3), 135-142. http:// dx.doi.org/10.1016/j.bej.2006.09.012

Sarimehmetoglu, B., \& Küplülü, Ö. (2004). Binding ability of aflatoxin M1 to yoghurt bacteria. Ankara Üniversitesi Veteriner Fakültesi Dergisi, 51(3), 195-198.

SAS Institute Inc. (1992). SAS ${ }^{\circledR}$ user's guide: statistics. Cary.

Scott, P. M. (1990). Natural poisons. In K. Helrich (Ed.), Official methods of analysis of the Association of Official Analytical Chemists (15th ed., pp. 1184-213). Arlington: AOAC.

Shahin, A. A. M. (2007). Removal of aflatoxin B1 from contaminated liquid media by dairy lactic acid bacteria. International Journal of Agriculture \& Biology, 9(1), 71-75.

Thipathi, P., Beaussart, A., Andre, G., Rolain, T., Lebeer, S., Vanderleyden, J., Hols, P., \& Dufrêne, Y. F. (2012). Towards a nanoscale view of lactic acid bacteria. Micron, 43(12), 1323-1330. PMid:22293169. http://dx.doi.org/10.1016/j.micron.2012.01.001

Van de Guchte, M., Serror, P., Chervaux, C., Smokvina, T., Ehrlich, S. D., \& Maguin, E. (2002). Stress responses in lactic acid bacteria. Antonie van Leeuwenhoek, 82(1-4), 187-216. http://dx.doi. org/10.1023/A:1020631532202

Walstra, P., Wouters, J. T. M., \& Geurts, T. J. (2006). Dairy science and technology (2nd ed.). Boca Raton: CRC Press.

Wehr, H. M., \& Frank, J. F. (2004). Standard methods for the examination of dairy products (17th ed.). Washington: American Public Health Association. http://dx.doi.org/10.2105/9780875530024 